Article

\title{
China: Some Exceptions of Secularization Thesis
}

\author{
Xianghui Liao ${ }^{1,2}$ \\ 1 Management School, North Sichuan Medical University, Nanchong 637100, China; liao132@purdue.edu \\ 2 Religious Studies Program, School of Interdisciplinary Studies, Purdue University, \\ West Lafayette, IN 47906, USA
}

Received: 26 November 2018; Accepted: 11 January 2019; Published: 16 January 2019

\begin{abstract}
The aim of this article is to present the controversial features of the secularization thesis about Chinese religions performed via analyzing the newly published Chinese religious policy named The Several Opinions on Further Governance of Commercial Problems in Buddhism and Taoism. This article proposes a complex hypothesis: (1) though the public influence of religion has acquired momentum of expansion in China, the growth and expansion of Chinese religions accompanied the decline of private religiosity; (2) Chinese religions possess controversial features of secularization: though they experience the reduction of their power, range of control, and prestige, meanwhile they embrace the increase in numbers of members, intensity, frequency, and importance of public life; (3) Nonreligious factors play an important role in promoting the growth of Chinese religions temporarily, while religious factors will be responsible for resurgence of Chinese religions chronically. This paper is the first in a series to apply the secularization thesis to Chinese religions.
\end{abstract}

Keywords: secularization; controversial features of secularization; Buddhism/Taoism; commercial problems of governance; China

\section{Introduction}

The secularization thesis has been full of controversy since it arose. One party claims that religion will lose its public influence as the forces of modernity advance. The other addresses that secularization as not a concept of sociology and should be eliminated. The overall picture is that sociologists overwhelmingly accepted secularization theory in the 1960s, and overwhelmingly rejected it by the late 1980s (Casanova 1994). Each of them provides abundant data to make their points. No matter how secularization theory is viewed, the entire body of secularization research still has predictive or explanatory value (Casanova 1994). The study of historical cases of secularization is still important (Berger 2014; Casanova 1994).

However, few data are serviceable to analyze Chinese religions in their characteristics and regulations of society. A newly published Chinese religious policy provides some new information to the secularization thesis. In order to govern commercial problems of Buddhism and Taoism that have appeared in Chinese society, the Chinese religious policy, The Several Opinions on Further Governance of Commercial Problem in Buddhism and Taoism, ${ }^{1}$ was jointly published by 12 ministries of China at the end of 2017. Why choose this policy to analyze Chinese religions? There are four national official documents issued which talk about religious affairs since the Communist Party of China took leadership in 1949. The first one is the Constitution of 1954, which was issued in wake of the construction of atheist China. The second one is the Constitution of 1982, which was issued in the wake of the ending of the Cultural Revolution. The Constitution of 1982 is the evolution of the Constitution of 1954. Both of

1 See http:/ / www.sara.gov.cn/xwfb/xwjj20170905093618359691/575692.htm. 
them guarantee all citizens religious freedom, which means every citizen of China has the right to be a religious adherent or not. The third one is an official document that was issued by the Central Committee of the Communist Party of China in 1982, named The Basic Viewpoint and Policy on the Religious Question during Our Country's Socialist Period. This document was issued at the beginning of the Reform and Opening-up of China. It provides a basic recognition of religion: "The political power in a Socialist state can in no way be used to promote any one religion, nor to forbid any one religion". In accordance with this document, a great number of religious problems all around the country have been resolved. The fourth one is the newly published official document, entitled The Several Opinions on Further Governance of Commercial Problem in Buddhism and Taoism, which was issued at the time of nearly 40 years' continuous economic development in China. The publishing of this religious policy was so widely involved with the different departments of central government and the CPC central committee, that it cannot fail to generate significant influence on Chinese religion and society because its issuers cover areas such as religion, security, finance, taxation, tourism, cultural heritage, cyberspace, securities, propaganda, etc. Admittedly, other religions such as Islam, Catholicism, and Protestantism also could be good or better examples to illustrate Chinese religions. That will be the later topic of research in this series.

Why choose secularization theory to discuss this religious policy? What implications does the governance of commercial problems in Buddhism and Taoism present in an age when secularization prevails? Penetrating explorations of the content of the religious policy show that what it addresses between the lines are three key features, namely, public influence of religion, attendance of religion, and belief in religion, which exactly are the three parameters of secularization theory. Specifically, the very beginning of the policy document presented the reason for issuing it as having to do with commercial problems of Buddhism and Taoism. This has been viewed as a problem by the public, and there is a need do something to guide and improve the social influence caused by religion. The policy listed 10 rules to deal with commercial problems. Among them, some important phrases are: "to promote social harmony", "to promote economic development", "to foster social ethos" all focus on public influence of religion; "not to promote religious fervor" points directly to attendance of religion; "to cultivate religious ethos", "to recover the qualities of nonprofit organizations", "to create a pure worship environment" all imply belief in religion. The authoritative viewpoints on secularization offered by Berger $(1967,1997,1999,2014)$ focus on public influence of religion, attendance of religion, and belief in religion; Finke and Stark (1992) and Stark and Finke (2000) mainly focus on attendance of religion; Stark and Bainbridge (1985) mainly focus on belief in religion; (Martin 1969; Warner 2010) focuses on public influence of religion, and attendance of religion; Norris and Inglehart (2004) mainly focus on public influence of religion; Bruce (2002, 2016), Voas and Chaves (2016, 2018), Crockett and Voas (2006), and Brauer (2018) all mainly focus on attendance of religion; Schewel (2018) mainly focuses on public influence of religion; Casanova (1994, 2018a, 2018b) mainly focuses on the importance of studying secularization and the value of studying East Asian religion in post-secular global age. This article attempts to propose several new aspects to secularization theory that emerged in Chinese society through analyzing the religious policy itself.

Especially, in light of the public influence of religion, attendance at religious sites, and belief in religion, all themes which the secularization thesis always focuses on, this article also argues that: (1) the secularization process has not proceeded as expected in atheist China; (2) if Chinese religions are studied according to secularization theories, several main differences could be easily observed; (3) though Chinese religions manifest several exceptional or even controversial features of the secularization thesis, these exceptions do not overturn the existing secularization thesis but offer certain constructive supplements.

\section{The Hypotheses of Secularization}

The thought of secularization can be traced back to Durkheim's individualism and Weber's rationality. But it was not exactly proposed until Berger's pluralism. Berger develops the imaginary 
trope of 'sacred canopy', and he maintains that with the eruption of pluralistic forms of religion, the 'sacred canopy' would be fractured and fragmented beyond repair. Then, discussions around secularization become enduring and irrefutable. A range of predominant points could be found in the following terms.

\subsection{Secularization is a Process}

Berger asserts that secularization is a process which began in ancient time. He makes a systematic and historical discussion of secularization in his book named The Sacred Canopy: Elements of a Sociological Theory of Religion. Firstly, the sacred is typically reaffirmed through a variety of rituals, and secularization is tantamount to the loss of them (Berger 1967, p. 27). Secularization is a process, by which sectors of society and culture are removed from the domination of religious institutions and symbols (Berger 1967, p. 107). Secondly, this process of secularization has existed since ancient time, as he contends that the roots of secularization are to be found in the earliest available sources for the religion of ancient Israel, the 'disenchantment of the world' begins in the Old Testament (Berger 1967, p. 113). Thirdly, the process of secularization has developed so rapidly and broadly that the religious legitimations of the world have lost their plausibility not only for a few intellectuals and other marginal individuals, but for broad masses of entire society (Berger 1967, p. 125). Moreover, secularization leads to pluralistic situations such as the fact that religion can no longer be imposed but must be marketed (Berger 1967, pp. 134, 144). The religious institutions become marketing agencies and the religious traditions become consumer commodities (Berger 1967, p. 137). What is worse, the consequence of the eruption of pluralistic forms of religion is (1) the dissolution of the 'sacred canopy' (which had always provided a society's homogeneous religious framework) and (2) the occurrence of the 'crisis of credibility' in religion (Berger 1967, p. 126).

Berger, however, made a complete volte-face about the paradigm shift in the sociology of religion with respect to the worldwide resurgence of religion. As he says,

"My point is that the assumption that we live in a secularized world is false ... The world today, with some exceptions... is as furiously religious as it ever was, and in some places more so than ever ... A whole body of literature by historians and social scientists loosely labeled 'secularization theory 'is essentially mistaken". (Berger 1999, p. 2)

Notwithstanding that Berger gives up his theory of secularization, he still argues that modernity undermines all the old certainties. Uncertainty is a condition that many people find very hard to bear; therefore, any movement (not only a religious one) that promises to provide or to renew certainty has a ready market (Berger 1999, p. 7). Specifically, religious resurgence has, according to Berger, appeared and will extend to the future for two crucial reasons. The first one originates from religion itself. Berger argues that religion can offer certainty to the uncertainty that is caused by modernity, and then shake the foundation of elite culture in which the secular view is located. The second reason derives from what religion is in relation to, such as international politics, war and peace, economic development, human rights, and social justice (Berger 1999, pp. 11-17).

Berger proposes secularization theory only later to abandon it. Why does Berger propose secularization theory? He holds that religion manifests itself as private virtue in which religion is a matter of choice or preference of the individual. Private religion cannot construct a common world. Why does Berger give up secularization theory? He holds that religion manifests itself as public rhetoric in which religion is connected to international politics, economic, and society. It is under this narrative that religion has got its resurgence. In fact, what Berger noticed are the three aspects of secularization theory, namely, public influence of religion, attendance of religion, and belief in religion.

\subsection{Secularization is Not a Scientific Concept}

Martin proposes that secularization is less a scientific concept than a tool of counter-religious ideologies, and that the uses of secularization are a barrier to progress in the sociology of religion 
(Martin 1969, p. 9). Martin addresses the misuses of the secularization concept as due to two substantive reasons. First, there is no direct comparison between the religious and the secular. The exact reason is that the religious and the secular are just like two poles with no exclusive associations in logic or in practice. And if there are no exclusive associations between one polar alternative and any related set of alternatives, no sets of criteria can be utilized to distinguish the religious from the secular (Martin 1969, pp. 12-13). Second, there is no unitary process called 'secularization' that arises in reaction to a set of characteristics labeled "religion". The whole concept appears as a tool of counter-religious ideologies (Martin 1969, p. 16). Therefore, the word secularization is too closely linked to ideological distortions to be retained. Secularization should be erased from the sociological dictionary (Martin 1969, p. 22).

Despite his negative attitude toward the secularization thesis, Martin still makes a deep analysis of it. He proposes two major types of secularization, one, which includes the process whereby religious passion succumbs to bureaucracy and adjusts itself to politics, power, and authority, and a second of sectarianism which converts the symbols of ecclesiastical religion into terrestrial realities (Martin 1969, p. 23). He identifies the main marks of secularization as the decline of ecclesiastical institution in its power, wealth, influence, range of control, and prestige, the close relations of ecclesiastical institution to the wider society and its power structure, the diminution of religious customs, practices, and rituals in their frequency, number, and intensity, and in the estimate of their importance and efficacy (Martin 1969, pp. 48-50).

Nevertheless, nearly 40 years later, Martin revised his original proposal about secularization and titled it "On Secularization: Towards a Revised General Theory". In his new theory, Martin identifies secularization as a recurrent process which is shaped by the successive forms of the dominant framing of the interaction of Christianity with the prevailing culture (Warner 2010, p. 47). Stark also has a negative attitude towards the notion of secularization. Factually, as early as 1985, Stark and Bainbridge put forward the idea that secularization is nothing new, that it is occurring constantly in all religious economies. Secularization could be regarded as the primary dynamic of religious economies, a self-limiting process that engenders revival (sect formation) and innovation (cult formation) which, due to their initial otherworldliness, are reduced and worldliness is accommodated (Stark and Bainbridge 1985, pp. 429-30). In light of the historical data from the American religious market share that they studied, Stark and Finke build upon church-sect theory and propose that the growth of cities increased religious participation (Finke and Stark 1992, p. 204). Then, in their subsequent study, Stark and Finke take into account the idea that secularization built upon the hypothesis of modernization would suffer inherent incompatibility with religion, and they acknowledge that religion might wither, but it is not a direct result of modernization. So, they argue that after nearly three centuries of utterly failed prophesies and misrepresentations of both present and past, it seems time to carry the corpse of the secularization doctrine to the graveyard of failed theories (Stark and Finke 2000, p. 79).

Though Martin makes a change toward secularization from thoroughly negating it to a limited acceptance of it, what he focuses on mostly are: public influence of religion and attendance of religion. Stark and his co-authors focus on belief in religion and attendance of religion. Early on, they propose, based on their comparison of otherworldliness and worldliness, that secularization as a result of rational choice will occur in all religious economies. Later, noticing the increase of religious participation, they abandon secularization theory completely. Martin, Stark, and his co-authors all experience the shift of recognition of secularization theory.

\subsection{Secularization is a Trend}

Norris and Inglehart develop a new theoretical framework for understanding how the experience of existential security drives the process of secularization. Firstly, they draw a conclusion about existing secularization theories, such as, there are two main voices about secularization. One is characteristic of the twentieth century, which adheres to the death of religion, the other is characteristic of recent decades, one which is suspicious of secularization. Two assumptions lie behind secularization 
theories: a demand assumption or a supply assumption. From the perspective of demand, as societies industrialize, almost regardless of what the religious leaders and religious organizations attempt, the public will become indifferent to spiritual appeals gradually. From the perspective of supply, the public demand for religion is constant and any cross-national variations in the vitality of spiritual life are the product of its supply in religious markets (Norris and Inglehart 2004, p. 7). Secondly, they propose that the secularization theories in the demand-side are correct based on their investigation of the rational weltanschauung, functional evolution, theory of religion markets, the thesis of secularization based on existential security, and other hypotheses. Thirdly, they argue that due to considerations of social security, secularization is a mere tendency, and those suggestions that secularization theory should be buried are premature. Moreover, the role of religion and how to understand and view the sacred and the secular are important issues. These issues should be elevated to the international agenda. As they say,

Due to rising levels of human security, the public of all advanced industrial societies have been moving toward more secular orientations. Secularization is occurring in most advanced industrial societies. Due to demographic trends in poor societies, the world as a whole now has more people with traditional religious views than ever before-and they constitute a growing proportion of the world's population. The expanding gap between sacred and secular around the globe has important consequences for cultural change, society, and world politics, raising the role of religion on the international agenda. (Norris and Inglehart 2004, pp. 6, 24-26)

Bruce also announces that the theses of secularization should be more than a mere trend in his recent published essay titled The sociology of late secularization: social divisions and religiosity. On the basis of observation of a number of social and demographic characteristics of the religious and the religiously indifferent in UK, Bruce urges that despite the apparent death of the secularization thesis, an additional barrier, caused by the relationships between the religious and the religiously indifferent, gives good reason to see secularization as more than a mere trend, and the fact that being religious is now associated with particular minority populations makes it remarkably unlikely that the religiously indifferent majority will convert at a rate required to reverse the trend of decline (Bruce 2016, p. 629).

Additionally, Voas and Chaves presented a new perspective on US religion after they explored the decline of generational religious affiliation and attendance in European countries. They develop the claim that the United States is not a counterexample to the secularization thesis in their article titled Is the United States a Counterexample to the Secularization Thesis? (Voas and Chaves 2016, pp. 1517-56). When Bruce declares that the narrow demographic base of the religious makes the reversal of secularization unlikely in UK, Voas and Chaves propose that the United States should no longer be considered a counterexample to the secularization thesis. They employ the data that include the BSA survey data in Great Britain, the population census data in Australia and New Zealand, the GSS data in Canada and in the United States. They employ three steps to analyze the data that include: (1) the graphical examination of the data, (2) the employment of Firebaugh's decomposition technique, and (3) the combination of graphical evidence and decomposition results to draw conclusions about what combination of age, period, and cohort effects most likely produced the patterns they observe (Voas and Chaves 2016, pp. 1525-40). Then, they draw the following conclusion that the central result for Great Britain, Australia, New Zealand, and Canada is easy to state: secularization has occurred mainly, in some cases entirely, because each successive generation is slightly less religious than the one before it and, for this reason, religiosity has been declining in the United States for decades. Religious commitment is weakening from one generation to the next, and the same pattern of cohort replacement is behind American religious decline. In 2018, Voas and Chaves argue for the decline of religiosity in America once again. They develop the thesis that even the intensely religious segment of the American population is shrinking because religious affiliation, belief, and practice in the United States have been declining for decades (Voas and Chaves 2018, pp. 694-710). Furthermore, Voas and his co-author propose that cohort replacement is the primary driver of religious decline which is long 
term and hard to reverse, because children are raised by parents who are less religious than their parents were, and the culture is gradually reshaped with the passing of each successive generation (Voas and Chaves 2016, pp. 1540 and 1548). Brauer confirms the hypothesis of self-reinforcing theory of decline in religion. He asserts that self-reinforcing theories fit within the study of secularization, but do not require the secularization paradigm's strongest assumption. He wonders how religious decline can be a self-reinforcing process, and he proposes that religious growth may also be self-reinforcing in particular contexts and there may be a self-reinforcing mechanism that starts or enables a process that takes on its own trajectory (Brauer 2018, pp. 654-75).

Norris and Inglehart focus on public influence of religion. They assert that the role of religion should be raised to international agenda due to social security and the expansion of the gap of religious adherents between advanced industrial societies and poor societies. Bruce focuses on attendance of religion in UK. He argues that it is impossible that the particular minority populations of the religious and the religiously indifferent majority will convert. Voas and his co-author focus on attendance of religion and belief in religion in US. They propose that religiosity is declining through generations; even the intensely religious segment of the American population is shrinking. The cohort replacement pattern of decline in religion (proposed by Voas) and the self-reinforcing pattern of decline in religion (proposed by Brauer) still focus on attendance of religion. Norris, Inglehart, Bruce, Voas, Chaves, Crockett, and Brauer all insist that secularization is a trend.

\subsection{Secularization is a Post-Secular Problem}

Schewel proposes a new term post-secular problematic in his article titled Post-Secularism in a World-Historical Light: The Axial Age Thesis as an Alternative to Secularization (Schewel 2018). Schewel employs this term to describe the current state of narrative perplexity regarding the changing place of religion in the modern world. Why does he employ the term 'post-secular'? There are three plausible reasons: (1) to acknowledge the central and enduring role of religion in public life that goes beyond the longstanding secular-religious divide, (2) to acknowledge the efforts of religious actors to constructively transform the patterns of collective existence upon which public life depends, and (3) to acknowledge how insights from different religious traditions could be used to reconceptualize the very relationships that sustain public life between individuals, communities, institutions, and reality as a whole.

Schewel focuses on the public influence of religion and coins a new term post-secular problematic to describe the current state of religion in modern world.

In conclusion, secularization theories are full of controversy because they are generated by different perspectives or data sources employed by researchers. Even the same theorists, such as Berger, Stark, and Martin, offer disparate recognitions of it during different times and with respect to different social spheres. Possible agreement between the theories is that secularization is a recurrent process, rather than a linear one as was proposed by Berger early on. Consequently, it is said that secularization is a process whereby religious beliefs, practices, and institutions lose social significance as measured by religious attendance, commitment to orthodox belief, support for organized religion in terms of payments, membership, and respect, and by the importance which religious activities such as festivals assume in social life (Scott 2015). Secularization itself, however, is too complicated a task to be fulfilled completely because two essential modes of being called 'the sacred' and 'the secular' exist. They have always run on parallel traces or interacted with each other from the past to the future. Religious and nonreligious people coexist, though there remain direct or indirect observed differences. Moreover, due to the proportion and social roles performed by the religious and nonreligious people, the gap between the sacred and the secular has appeared, remained, even expanded in different societies and cultures and will continue to have potential and far-reaching influence for culture, society, and world politics. Meanwhile, secularization has different features in different religious systems and different societies. Especially, three parameters of secularization were abstracted from western religions, namely, public influence of religion, attendance of religion, and belief in religion. Their 
possible tendency to change and predictable results will encounter some exceptions when applied to eastern religions, such as religions in China.

\section{The Chinese Religious Policy on Commercial Problems Governance}

The Chinese religious policy The Several Opinions on Further Governance of Commercial Problems in Buddhism and Taoism was newly published by 12 ministries of the Chinese central government at the end of 2017. The publishers included: the State Administration for Religious Affairs, Central Propaganda Department, United Front Work Department of the CPC Central Committee, Office of Central Cyberspace Affairs Commission, National Development and Reform Commission, Ministry of Public Security, Ministry of Finance, Ministry of Housing, and Urban-Rural Development, State Administration of Taxation, State Administration of Tourism, State Administration of Cultural Heritage, and China Securities Regulatory Commission. The publishing of this religious policy so widely involved different sectors that it promises to generate significant influence on Chinese religions and society because its issuers cover areas such as religion, security, finance, taxation, tourism, cultural heritage, cyberspace, securities, propaganda, etc. For this reason, it is a good example by which to analyze the situation of Chinese religions.

\subsection{What the Religious Policy Regulates}

The religious policy proposes that Buddhism and Taoism have developed smoothly during recent years and have had positive impacts on social harmony and promoting economic development. However, some problems arose, among which commercial problems have attracted the most public attention. The sound development of Buddhism and Taoism will suffer unless these problems are resolved properly. Even worse, it will have negative effects on social ethos, and trigger corruptions, such as seeking power for personal advantages, unscrupulous deals, etc.

In order to deal with commercial problems arising in Buddhism and Taoism, 10 rules were proposed in this document, as follows.

- To be clear that the essential quality of Buddhism and Taoism places of worship are nonprofit, commercial capital should be strictly prohibited from involvement in Buddhism and Taoism.

- To prohibit holding activities and seeking benefits in the name of Buddhism or Taoism, the scenic spots, which for sightseeing are the places of worship of Buddhism or Taoism, should not charge high ticket prices. The cultural scenic spots related to Buddhism or Taoism should be controlled strictly.

- The creation of huge religious statues in the open air beyond religious venues should be forbidden. No organizations or individuals will be allowed to invest in building or making a profit from huge religious statues in the open air.

- The activities of burning incense and liberating animals should be regulated, to guide religious people to cultivate an awareness of the necessity to protect environment.

- In order to strengthen internet information management, religious services offered on-line should be subject to the censorship of provincial bureau of religious affairs and should obey the regulations of national internet information management and religious affairs management.

- The earnings from the activities of running places of worship of Buddhism and Taoism should be used to maintain religious venues or support charities.

- To strengthen financial management of the communities and worship sites of Buddhism and Taoism, the places of worship of Buddhism and Taoism should execute the national unified system of finance, taxation, asset management, accounting, transparent balances of organizational bank accounts, and complete taxation registration according to law.

- Guide Buddhism and Taoism to recognize and cope with commercial problems, cultivate religious ethos, and consciously resist the temptation to chase profit and engage in commercial activities. 
- View the role of religion dialectically, so that government does not promote religious fervor in the name of development of economy, tourism, and culture. The government and its staff should not seek benefits from religious affairs.

- Commercial problems of Buddhism and Taoism should be dealt with according to laws and regulations. All bureaus should promote governance of commercial problems in cooperation with each other.

Obviously, among the 10 rules addressed in this religious policy, 5 requirements focused on Buddhism and Taoism to withdraw from commercial activities and to return to the sacred field, 3 requests focused on secular organizations, i.e. local governments, economic organizations, and individuals to regulate their behavior to prevent religions from commercial permeation, and 2 items on the two sides to cooperate. Specifically, regulations for Buddhism and Taoism are these: to recover their qualities of nonprofit organizations, to foster religious ethos, to create a pure worship environment, to utilize their earnings to maintain themselves, to be in conforming with the laws of finance and taxation. Regulations for secular organizations are these: to forbid secular organizations from running events in the name of Buddhism and Taoism, to preserve the line between what is religious and what is nonreligious, to deal with commercial problems of religious sites according to law. Regulations for the two parties' cooperation are these: to enhance governance of internet information about religion, to forbid the creation of huge religious statues in the open air beyond religious sites.

\subsection{Why the Religious Policy Issued}

What implications does the governance of commercial problems in Buddhism and Taoism present in the age of secularization? In accordance with the religious policy itself, first, Buddhism and Taoism have played constructive roles to promote social and economic development during recent years. Second, Buddhism and Taoism have transformed their sacred symbols into terrestrial realities to seek fame and wealth; this has been viewed as a problem by most of the public. Third, secular organizations have intruded into sacred territory to seek fame and wealth and this has also been viewed as a problem most by the public. Fourth, the decline of religious ethos occurs when Buddhism and Taoism engage in commercial activities. Fifth, religious fervor, which means religions grow rapidly and unexpectedly, emerges when both religious organizations and secular organizations seek fame and wealth in the sacred territory. Sixth, there is social chaos when individuals seek power for personal advantages and engage in unscrupulous practices without legal and proper public governance.

Obviously, there are two purposes to this religious policy. One is to promote the development of Buddhism and Taoism well, the other is to regulate secular organizations to foster sound social ethos. However, there is really only one aim intended by this policy. On further analysis, the real purpose is to guide and improve the social influence caused by commercial problems of Buddhism and Taoism. What the government notices is that religious commercialization would trigger problems of religious ethics and then impact social ethos. Hence, it is safe to say that the key words and ultimate goal of the Chinese religious policy are a response to the public influence of commercial problems that arose in Buddhism and Taoism.

Nevertheless, the public influence of religion is one of the crucial issues of the secularization thesis. Theorists have disputed and been divided around it. Also, it is not hard to find out some clues for the other two issues that the secularization thesis focuses on-religious sites attendance and religious belief. At the time most of the world experienced a decline of religions, Chinese religions have grown along with their social development. That is one of the issues secularization thesis focuses on-the attendance of religious sites will increase or decrease due to the development of modern society. At the time, spirituality (instead of religiosity) became the aim of religious practice for increasing numbers of people in the world, Chinese religions embraced commercialization at the expense of corrosion of religious ethics. That is one of the issues secularization thesis focuses on-the belief that religion will enhance or weaken due to the development of modern society. Consequently, it is evident that 
the information supplied by the Chinese religious policy would add some new understanding to the secularization thesis as well as provide some exceptions to it.

\section{Certain Constructive Supplements to Secularization Thesis that Chinese Religions Manifest}

Generally, the secularization thesis claims that there are three forms of secularization: the decline in religious beliefs, the decline in religious practices, and the decline of religion in public life (Warner 2010, p. 107). It also maintains that there are three parameters to measure the scale of secularization: the degree to which social life is secular, the shrinking of church attendance, and the dissolution of the sacred (Gao 2017, pp. 1132-36). Moreover, most of the scholars of secularization hold that religion will lose its public influence as the forces of modernity advance. However, due to the apparent "resurgence" of publicly influential religion throughout the world in recent years, scholars have recognized that a "straightforward narrative of progress from the religious to the secular" is no longer viable (Schewel 2018, p. 139). Especially, several exceptions occur when one applies the secularization thesis to religions in recent China. And these exceptions do not overturn the existing secularization thesis but offer certain constructive supplements.

\subsection{Public Influence and Recent Chinese Religions}

Public influence of religion is the pivotal idea theoreticians of sociology of religion discuss. Durkheim thinks that religion is profoundly important. Indeed, it is essential to the articulation and enactment of social cohesion. The enemy of social cohesion and religion, alike, is excessive individualism. Moreover, individualism tends to become overstated at the expense of the communal, self-obsessed, and socially divisive (Warner 2010, p. 22). Weber considers that the forces of social interaction between religion and society are immensely complex and work in both directions. At times, religion is shaped by social forces; at other times, religion reconfigures the society in which it operates. And it is modernity that has brought about a momentous disruption of the interconnections of religion and society (Warner 2010, pp. 24-25). Berger advances the thesis that religion manifests itself as public rhetoric and private virtue. Privatized religion is a matter of the 'choice' or 'preference' of the individual or the nuclear family lacking in a common, binding quality. Private religiosity can no longer fulfill the classical task of religion which is to construct a common world within which all of social life binds everybody ultimately (Berger 1967, pp. 132-33). Notwithstanding, Berger later gives up his theory of secularization due to the global resurgence of religion. One of the reasons he concludes this stems from the relationships among religion and international politics, war and peace, economic development, human rights, and social justice (Berger 1999, pp. 11-17). In other words, Berger develops a secularization thesis addressed to the change occurring in religion as it was being diminished from an all-encompassing to a narrow and specialized domain. He changed this thesis in light of the interaction between religion and other social forces. No matter what the investigator's attitude towards secularization thesis, the cause is the public influence of religion. Although Martin takes a negative attitude towards secularization thesis, he makes a profound analysis of it. He proposes that one of the major types of secularization was the process whereby religious passion succumbs to bureaucracy and adjusts itself to politics, power, and authority (Martin 1969, p. 23). And one of the marks of secularization is concerned with any decline in power, wealth, influence, range of control, and prestige of the ecclesiastical institution (Martin 1969, p. 48). Furthermore, Martin declares these notions to be based on Christianity, but he still urges that perhaps the bureaucratic aspect has been more characteristic of western Christendom, while the fusion with temporal authority has been more characteristic of eastern religions (Martin 1969, p. 23). What Martin presents above is the idea that secularization means the decline of public influence of religion. There are no words to describe the public influence of religion, yet implicitly what Martin maintains is related to it. Moreover, Wilson states directly that secularization is the process whereby religious thinking, practice, and institutions lose social significance (Wilson 1966, p. 14). Unfortunately, Norris and Inglehart, being different from most theorists who maintain a decreased trend of public influence of religion, acknowledges that the 
role of religion should be raised to the international agenda due to the expansion of secular degrees in different societies and its consequences for cultural change, society, and world politics (Norris and Inglehart 2004, pp. 6, 25, 26). Put differently, it is not advisable to argue that there is a decline of public influence of religion due to secularization occurred in most advanced industrial societies, because there are also more people with traditional religious views in poor societies, and they are part of a growing population. This situation will generate a variety of gaps between the sacred and secular, which will bring about estrangement of culture and result in increased insecurity.

Evidently, the public influence of religion is a threshold for most sociologists of religion. The majority of them hold that the public influence of religion will diminish with modernization, and it will be accelerated when major government departments begun under the aegis of the church become and function as secular institutions. A minority of sociologists imply its importance for the world development in modern and divided society. No matter what side they stand on, they all concentrate on the public influence of religion. Because of all of these implications, it is possible that society would be more sacred when the public influence of religion is enhanced and increases continuously, and society would be more secular when the public influence of religion is weakened and decreases.

Penetrating explorations of the content of the Chinese religious policy show that what it addresses are all about the public influence of religion. To be specific, firstly, the document states that Buddhism and Taoism have a positive impact on maintaining social harmony and promoting economic development, that is to say, Buddhism and Taoism have had some influence in the public field. Secondly, the document was written and issued because commercial problems of Buddhism and Taoism were most noticed by the public, that is to say, that this religious problem has most affected the public. Thirdly, the document observed that the social ethos would be influenced due to decreased religious ethos when Buddhism and Taoism converted their sacred symbols into terrestrial realities in order to acquire fame and wealth, that is to say, religious values would produce some effect on society. In a word, the reason that the central government takes commercial problems of Buddhism and Taoism as a public issue that should be addressed, immediately, is because of the public influence it generates and will generate continuously in the future.

Therefore, it is unambiguous that the public influence of religion has not only resurged but has also increased continuously, so much so that, when both secular and religious organizations seek fame and wealth, the Chinese central government must require local governments to view the role of religion dialectically and guard the boundary of the sacred and the secular in order to decrease the public influence of religion. In other words, at the very moment that the public influence of religion has suffered considerable shrinkage in the rest of the world, it has acquired the momentum of expansion in China. Consequently, with respect to the public influence of religion, it is beyond all doubt that the overall situation of religion in China deviates from the secularization thesis somewhat.

\subsection{Attendance and Recent Chinese Religions}

Attendance at religious sites is another essential issue that the secularization thesis focuses on. The attendance survey has a long historical and complicated task to fulfill. The census of religious worship was a part of the government census of population in Great Britain. The last one was conducted in England, Wales, Scotland in 1851. But the data it reported were dubitable because attendance on any particular Sunday could be distorted by bad weather, other events, or multiple attendances. After that, theorists proposed new tools of measurement to reveal church attendance, such as affiliation, formal membership, and counting actual attendees. Also, there are two typical empirical measures: frequency, which means churchgoing over a given period of time, or presence, which means actual attendees at church on one or more Sundays (Rossi and Scappini 2014, pp. 249-67). However, church attendance rate has been criticized for overestimate or over-reporting. No matter what methods utilized, it is unambiguous that religious attendance has been experiencing unremitting shrinkage. Probably, this is the main reason that numerous sociologists of religion make the sign of secularization the decline of attendance at religious sites. Bruce describes the continuous decline 
of church attendance as 'the death of God' (Bruce 2002). Martin holds that one of the features of secularization means the diminution in the frequency and number of religious practices and rituals, and the simplest level of secularization means that there is less frequent attendance at church services of all kinds and less religious observance in the home (Martin 1969, p. 50). Stark and Finke bring up the point that institutional churches have lost ground to a free religious market. The mainline bodies are headed for the sideline (Finke and Stark 1992, p. 275). Hadaway and Marler declare that actual church attendance in the United States has declined for mainline denominations. Actual weekly church attendance in the United States was around 20 percent (Hadaway and Marler 2005, pp. 307-23). Warner argues that dimensions of religion in America did not conform readily to the classical European paradigm, due to the continuing high levels of church attendance and that the reigning theory does not seem to work. This has become an open secret (Warner 2005, p. 21). Voas and Chaves urge that religiosity has been declining in the United States for decades; religious commitment is weakening from one generation to the next. The same pattern of cohort replacement is behind American religious decline. The United States should no longer be considered a counterexample to the secularization thesis (Voas and Chaves 2016, p. 1548). Even the intensely religious segment of the American population is shrinking (Voas and Chaves 2018, p. 695). Vezzoni and Biolcati-Rinaldi propose, on the basis of a pooled analysis of repeated cross-section surveys that span over four decades, that the trend of attendance at Mass in Italy has decreased since the 1960s until today; the overall trend looks like a "recumbent S" trend (with a decrease up to the 1970s, stability in the 1980s, and a decrease afterwards). For this reason, a religious revival in Italy would not be probable (Vezzoni and Biolcati-Rinaldi 2015, pp. 100-18).

Why does this situation of decline of church attendance happen? It is universally said that church attendance is affected by the quality of the religious market-higher in a deregulated market and lower in a regulated one. One research team presented the idea that "modernization corrodes church attendance to a larger extent than deregulation can stimulate church attendance", based on their multilevel analysis of European and World Value Surveys of 1981, 1990, 2000, and 2006 (Aarts et al. 2010, pp. 657-72). By using panel regression models to a new dataset (which spans a period of 40 years and includes 51 countries from all European regions, Australia, and New Zealand, and the Americas), another team reported: that (1) tertiary education and individualization proved to be a strong predictor of changes in church attendance, (2) economic development (GDP) and life expectancy were negatively related to changes in church attendance, (3) there is little support for the idea that a growth of social security or a reduction of income inequality furthers church attendance, (4) social globalization and social benefit policy did not support it as well, and (5) income inequality and urbanization were driving forces of change during the 1970s and 1980s, but not since 1990 (Van Ingen and Moor 2015, pp. 558-69). Still, one team only focused on the life course of church attendees to uncover its effect on church attendance by using data collected longitudinally over the course of up to 34 years (between 1971 and 2005, and with ages ranging from 15 to 102). They found an average pattern of quadratic decline in adolescence, stability in middle adulthood, and a quadratic pattern of more rapid increase followed by decrease over the course of older adulthood (Hayward and Krause 2013, pp. 1480-89).

\subsubsection{Religious Fervor Measured by Numbers}

What is the exact situation of Chinese religions? Few data are serviceable to analyze Chinese religions in the international context. Maybe the reason is that different religions have different styles of worship. For instance, Christianity and Islam have the tradition of weekly attendance, but Buddhism and Taoism do not. Perhaps the reason is that polytheists attend rituals across religions. Monotheists usually do not. This makes statistical studies meaningless.

The two words religious fervor, however, could easily be used to characterize participation in Chinese religions. Religious fervor has occurred and has been an issue in recent China and this is reflected in the ten regulations of religious policy. There, it is proposed "to view the role of religion 
dialectically, the government should not promote Religious fervor in the name of development of economy, tourism and culture". Furthermore, that religious fervor is mentioned in Chinese religious policy, in that it asks local governments not to promote it, confirms that religious fervor has existed and will continually develop if it is not controlled properly.

Religious fervor means religions grow rapidly and unexpectedly, which is similar to the term of "re-enchantment" in western society. It used to describe the rapid growth of religion in Chinese rural areas. Rural China has been undergoing the 'religious fervor' since the Reform and Opening-up (Ruan et al. 2016, pp. 170-90). Factually, the social phenomenon of religious fervor is not limited to rural areas but spreads all over the country. Buddhism and other popular religions have also experienced remarkable growth. Churches and temples were overcrowded in the wake of the Cultural Revolution, struggling to accommodate the towering number of believers (Gao 2017, pp. 1132-36).

Why does religious fervor occur in atheist China? Three reasons might give us an answer. The first reason is related to regulations of the society. Generally, religions either grow slowly or even decrease, when they are exposed under high suppression. But they will grow rapidly when they shift from high to low regulations. This situation can be confirmed by religious change after the Cultural Revolution, especially after the Reform and Opening-up. As it is said,

... The constant political movements from 1949 up to the Cultural Revolution swept away the traces of religious life at both social and administrative levels. It was through such seismic shifts in ideology as well as in social structure that the secularizing process in Chinese society reached its peak. The end of the Cultural Revolution, however, reversed this process ... Under the impact of reforms, the sacredness of religion also experienced a drastic turn. (Gao 2017, pp. 1132-36)

\subsubsection{Religious Diffusion in Every Aspect}

The second reason is characteristic of Chinese religions, which is famous for being diffused in every aspect of life. People who hold that he or she is not a member of one specific religion might visit different religious places according to their latest needs, including a Buddhist temple, a Taoist temple, a Confucian temple, even a Catholic church, a Protestant church, and a Mosque if they were permitted. They also engage in some religious consumption and pray as adherents. So, it would not be surprising that the number of visitors of religious sites rises unexpectedly when institutional religions gain a place in traditional culture and develop because of places of worship and tourism. The third reason originates from the secularization thesis itself. The viewpoints of some scholars illustrate this. Martin holds that: (1) secularization means that religious passion succumbs to bureaucracy and adjusts itself to politics, power, and authority, and (2) sectarianism converts the symbols of ecclesiastical religion into terrestrial realities (Martin 1969, p. 23). Yang proposes that there are two special points of secularization for Chinese religions-religions become vulgar, rather than sacred, religions convert supernatural world into realistic world (Yang 2007, pp. 17-20). The insights of Yang have been demonstrated via commercial problems that emerged in Buddhism and Taoism. Hence, it is because of the deregulation of society, the diffused nature of religions, and their embracing of some features of secularization, that religious fervor is generated in Chinese society.

Therefore, it is evident that Chinese religions have experienced fast and continual growth, meanwhile most religions of the world have suffered decline and shrinkage. Especially, growth occurs unexpectedly, when both secular and religious organizations seek fame and wealth. Consequently, with respect to attendance at religious sites, it is beyond all doubt that this characteristic of Chinese religions deviates from the secularization thesis somewhat.

\subsection{Belief in Religions and Recent Chinese Religions}

Belief in religions is also the most important issue that the secularization thesis values. Belief in religions, following public influence of religions and attendance at religious sites, occupies a significant position in the narrative of sociologists of religion. This is derived from a surprising result of a survey 
in which a team from Lancaster University wanted to survey the patterns of religious participation in Kendal, which was a typical English provincial town in 2001. They found two results: one is a low level of church attendance; the other is a high level of involvement in emergent spiritualities which was extensive and highly diverse. Moreover, churches and spiritualities inhabit two distinct worlds, with little blurring of the boundaries and few participants engaging in both domains (Warner 2010, p. 90). These researchers wrote a book about their discoveries, titled The Spiritual Revolution. There, they say,

Survey after survey shows that increasing numbers of people now prefer to call themselves 'spiritual' rather than 'religious' ... Christianity has a new competitor in 'the spiritual marketplace'. (Heelas et al. 2005, p. 1)

Partridge also asserts alternative spiritualities and 'soft religion' will increase in significance in the West (Partridge 2004, p. 188). Another survey, the Tearfund churchgoing survey (Ashworth and Farthing 2007), indicates that 53 percent of respondents claimed to be Christian, 6 percent are aligned with other faiths, but 39 percent describe themselves as having no religion (Warner 2010, p. 160). However, The European Values Survey (Halman 2001) indicates a continued resilience of traditional religious beliefs and practices, with the limited foothold of absolutist atheism and the emergence of post-Christian or post-theist spiritualities and attendant convictions (Warner 2010, p. 104).

\subsubsection{Data from Chinese Religious Survey}

After 2000, three Chinese academic institutions also set about surveying national religions. One was conducted by a team from the Chinese Academy of Social Sciences, which has surveyed and has reported annually, since 2008. It reported about the development of five Chinese institutional religions (Buddhism, Taoism, Islam, Protestantism, and Catholicism) and Folk religion in the book Blue book of Religions: Annual Report on Religions in China (xx year). The other survey, Chinese General Social Survey (CGSS), was conducted by a team from Renmin University of China. It sampled thousands of households across the country in 2006, 2008, 2010, and 2011. The third one, China Family Panel Studies (CFPS), was conducted by a team from Beijing University which surveyed in 2010, 2012, and 2014. Two Chinese scholars of Sociology of Religion collected the data of the above three, especially the latter two, and they provide a table of Chinese adults belief distribution (between 2006 and 2014) in their article called Observation in Present Situation of Contemporary Chinese Christian: Based on the Survey Data from CGSS and CFPS (Lu and Zhang 2016, pp. 34-46, 158). According to Lu and Zhang, more than 70\% of Chinese adults are nonbelievers. This is the largest group. Buddhism occupies the second position whose proportion is about $15 \%$, Protestantism occupies the third position, which is about $2 \%$, and the proportion of other religions is all less than $1 \%$.

However, what the statistical data of Chinese religions express is a far cry from the data derived from the western context for two reasons, i.e., polytheism and diffused religion. China is a society of polytheism. Put differently, a great number of Chinese worship different gods at different places and at different times according to their needs. Moreover, when asked whether they belong to one specific religion or not (especially traditional Chinese religions-Buddhism, Taoism, Confucianism, and Folk religion), they are always puzzled and find it hard to provide a best choice. Additionally, the fact that Chinese religions are diffused and spread through every aspect of life also leads to this phenomenon, namely, that the number of registered religious is much smaller than the number of those who really practice religion. This is also the critical reason that the position of Chinese religions is undervalued historically. In order to answer the question for what functions religion performs in Chinese social life and organization, the historian C.K. Yang applies a structural and functional viewpoint to probe Chinese religions and society. He proposes the concept of diffused religion. As he puts it,

We can discern two structural forms of religion. One is institutional religion, which has a system of theology, rituals, and organization of its own, independent of other secular social institutions ... The other is diffused religion, with its theology, rituals, and organization 
intimately merged with the concepts and structure of secular institutions and other aspects of the social order. The beliefs and rituals of diffused religion develop their organization system as an integral part of the organized social pattern. In the diffused form, religion performs a pervasive function in an organized manner in every major aspect of Chinese social life. (Yang 1961, p. 20)

Hence, it is could said that the data about adherents gained via statistical method, hardly indicate the factual situation of religious belief in China. Perhaps, it is more exact to employ the phrase 'believing without belonging', which is proposed by Davie, to expresses the states of religious belief of Chinese. Basing his study on older British people who are not church attendants, Davie applies this concept to emphasize that diminished participation has been accompanied by an enduring assent to underlying religious beliefs and moral values. (Warner 2010, p. 49)

\subsubsection{Commercialism and the Making of Statues}

Furthermore, as far as Chinese religious policy is concerned, some clues about the situation of Chinese religious belief can also be discovered. One of the regulations that Chinese religious policy states is that "The creation of huge religious statues in the open air beyond religious venues should be forbidden. No organizations or individuals will be allowed to invest in building or make a profit from huge religious statues in the open air". Two implications can be found in this regulation. One is that many huge religious statues have been created. The other is that commercial capital has been involved in the events creating huge religious statues. Although it carries commercial appeal, the enthusiasm to build temples and churches or to create religious statues causes continuous growth, it also can indicate the situation of religious belief, because most religions and their members have the motivation to create holy spaces and symbols in order to demonstrate their faith. For religions that traditionally create religious icons, the number and significance of holy symbols imply many followers. So, the requirement of the government (not to create huge religious statues in the open air), itself, on the other hand, suggests the growth of religious belief. Nonetheless, it is still possible to say that the growth of religious members and sites does not directly mean the increase of religious faith. One of the regulations that the Chinese religious policy presents is to "Guide Buddhism and Taoism to recognize and cope with commercial problems, cultivate religious ethos, and consciously resist the temptation to chase profit and engage in commercial activities". This is a good illustration of it.

Since the Reform and Opening-up, China has experienced continual religious growth for about 40 years, while most of the western developed countries experienced disenchantment in the late 20th century and re-enchantment or resurgence in the beginning of 21st century. The difference is that the growth of Chinese religions, such as Buddhism and Taoism, carries with it commercial benefit, i.e., some nonreligious people play an important role in promoting the development of religions, when they invest in religions to seek profit. Worse still, religious growth promoted by commercial capital has in turn hurt religions themselves. Therefore, a self-evident religious fact is that there has been a growth and expansion of religion accompanied by the decline of religiosity in China. Consequently, with respect to religious belief, it is beyond all doubt that the state of religion in China deviates from the secularization thesis somewhat.

\section{Conclusions}

\subsection{The Exact Reason for Choosing This Policy to Discuss Chinese Religions}

It is well known that there are three major cultures or spiritual branches of religion, i.e., Confucianism, Buddhism, and Taoism, in historical China. The dynamic integration of Confucianism, Buddhism, and Taoism is also termed sanjiao. Buddhism or Taoism has never earned a dominant position, Confucianism had lost its status since the New Culture Movement happened in 1919. The Communist Party of China took leadership and declared its' standpoint of atheism 
beginning in 1949. Then, atheism became main stream in Chinese society. Since then, atheists or non-specific-believers can be found anywhere in China. Especially, constant political movements from 1949 up to the Cultural Revolution swept away the traces of religious life at both social and administrative levels. and the secularizing process in Chinese society reached its peak around 1976 (Gao 2017, pp. 1132-36). In light of this point, it is safe to say that Chinese society is secular.

However, we cannot turn a blind eye to the fact that Chinese religions have increased so fast that a term, religious fervor, has been coined to describe this state. Mentioned in the religious policy, the local government should not promote religious fervor in the name of economics, tourism, or culture. This explicitly provides a clear and definite signal that not only does the phenomenon of religious fervor exist, but it will also have a continuous development. It has caught the notice of the central government. But to some extent, we must admit that religious fervor occurred in China promoted by commercial force.

This is why the religious policy, named The Several Opinions on Further Governance of Commercial Problems in Buddhism and Taoism, as a national one was jointly published by 12 departments of the central government and central committee of the Communist Party of China. Since the Communist Party of China took leadership in 1949, there are 4 national documents issued which talk about religion. Two of them are different versions of the Constitution, issued in 1954 and 1982 respectively, which make the foundation of religious freedom in atheist China. The third one issued in 1982, also called "Document 19", provides the basic method and thought for resolving the historical and current problems of religion. This policy is the fourth one to involve the national religious sites, organizations, events, and members. This policy will generate significant influence on Chinese religions and society simply because of the subject it focuses on and the time to it issued.

This is the exact reason that this article uses this policy to discuss Chinese religions. Admittedly, other religions such as Islam, Catholicism, and Protestantism also could be good or better examples to illustrate Chinese religions. That will be the later research topic of this series. Furthermore, the topic of this article is beneficial to better understand changing religion and society of China, even East Asia, because there is an urgent need to deconstruct and rethink in East Asian vernacular terms the categories of religion, secularity, and spirituality in order to offer a better understanding of changing East Asian religious fields (Casanova 2018a).

\subsection{The Exact Reason the Secularization Thesis was Chosen to Discuss This Policy}

Although, the secularization thesis has been full of controversy since it arose, and it has experienced overwhelming acceptance as well as overwhelming rejection. Nevertheless, the entire body of secularization research still has predictive or explanatory value (Casanova 1994). The study of historical cases of secularization is still important (Berger 2014; Casanova 1994). Between the lines of this policy, some words have special importance, such as, "social harmony", "economic development", "social ethos"; "religious fervor"; "religious ethos", "the qualities of nonprofit", "pure worship environment". Giving further analysis, the first group all focus on public influence of religion, the second group directly points to attendance of religion, the third group all imply belief in religion. Public influence of religion, attendance of religion, and belief in religion are the three parameters of secularization theory. This is the exact reason that the article chose secularization theoryto discuss the religious policy.

Public influence of religion is the pivotal idea theoreticians of sociology of religion discuss. The public influence of religion is a threshold for most sociologists of religion. The majority of them hold that the public influence of religion will diminish with modernization, and it will be accelerated when major government departments begun under the aegis of the church become and function as secular institutions. A minority of sociologists imply its importance for the world development in modern and divided society. In the 1960s, Berger developed the imaginary trope of 'sacred canopy', and he maintained that with the eruption of pluralistic forms of religion, the 'sacred canopy' would be fractured and fragmented beyond repair. The basic reason for this is that Berger urged that private religion cannot construct a common world. What Berger said is that secularization appears with the 
decrease of the public influence of religion. In the 1990s, Berger proposed that his secularization theory is false because of the resurgence of religion all over the world. But he said one of the reasons for resurgence is the connection between religion and other social forces of the world. What Berger said is that the resurgence of religion benefits from the increasing public influence of religion.

Martin takes a negative attitude towards secularization thesis, but he makes a profound analysis of it. What Martin holds is the idea that secularization means the decline of public influence of religion. Norris and Inglehart acknowledge that the role of religion should be raised to the international agenda because of the expansion of secular degrees in different societies and its consequences for cultural change, society, and world politics. Schewel coins a new term "Post-Secular problematic" for the apparent "resurgence" of publicly influential religion.

The sites, rituals, activities, and run events of Chinese religions attract the public to visit or participate. The public influence of religion has not only resurged but has also increased continuously when both secular and religious organizations seek fame and wealth. This phenomenon has generated huge social influence and became hot points of Chinese society. This is the basic reason that 12 departments of the Chinese central government and the CPC central committee jointly issued the policy to deal with commercial problems of Buddhism and Taoism, to view the role of religion dialectically, and to guard the boundary of the sacred and the secular. That government issues documents to govern religious affairs itself will generate social influence because many people of the world think it violates disestablishment. Anyway, in the end, this will increase the public influence of China's religions.

Attendance at religious sites is another essential issue that secularization theory focuses on. Berger gave up his theory of secularization in favor of a theory of the resurgence of religion all over the world. Bruce describes the continuous decline of church attendance as 'the death of God'. Martin holds that the simplest level of secularization means that there is less frequent attendance at church services of all kinds. Stark and Finke bring up the point that institutional churches have lost ground to a free religious market. Voas and Chaves urge that religious commitment is weakening from one generation to the next. Vezzoni and Biolcati-Rinaldi propose that attendance at Mass in Italy has decreased since the 1960s until today. Being different from the international data, few data are serviceable to analyze Chinese religions. Maybe the reason is that different religions have different styles of worship. Perhaps the reason is that polytheists attend rituals across religions. Probably the reason is related to regulation of society. However, the two words religious fervor can easily be used to characterize participation in Chinese religions. The policy requires local governments to view the role of religion dialectically, to guard the boundary of the sacred and the secular, and should not promote religious fervor in the name of development of economy, tourism, and culture. In other words, religious fervor has existed and will continually develop if it is not controlled properly. Religious fervor means religions grow rapidly and unexpectedly. Why does religious fervor occur in atheist China? The deregulation of society, the diffused nature of religions, and their embracing of some features of secularization all help to promote religious fervor.

Belief in religion is also the most important issue that secularization theory values. In the 1960s, Berger maintained that with the eruption of pluralistic forms of religion, the 'sacred canopy' would be fractured and fragmented beyond repair because private religion becomes a matter of individual choice and preference. In the 1980s, Stark and Bainbridge proposed that secularization as a result of rational choice would occur in all religious economies based on their comparisons to otherworldliness and worldliness. Voas and Chaves urge that religiosity has been declining in the United States for decades.

Belief in religion occupies a significant position in the narrative of sociologists of religion. This is derived from a survey which wanted to investigate the patterns of religious participation in 2001. But two results were found: one is a low level of church attendance, the other is a high level of involvement in emergent spiritualities. After 2000, three Chinese academic institutions also set about surveying national religions. According to the surveys, more than $70 \%$ of Chinese adults are nonbelievers, which is the largest group, Buddhism occupies the second position whose proportion is 
about $15 \%$, Protestantism occupies the third position, which is about $2 \%$, and the proportion of other religions is all less than $1 \%$. However, what the statistical data of Chinese religions express is a far cry from the data derived from the international context.

The data about adherents gained via statistical method hardly indicate the factual situation of religious belief in China. The regulations which were listed in the policy confirmed the appearance of religious fervor and the existence of abundant religious status in China. They are good illustrations of increasing religious members. However, the regulations which were listed in the policy to require Buddhism and Taoism to return to their sacred place also confirmed the decrease of religiosity of China's religion. So, the growth of religious members and sites does not directly mean the increase of religious faith. The growth of Chinese religions, such as Buddhism and Taoism, carries with it commercial benefit, i.e., some nonreligious people play an important role in promoting the increase of religions. China's religion has experienced a growth and expansion accompanied by the decline of religiosity.

\subsection{Some Controversial Features of the Secularization Thesis Indicated by Chinese Religions}

It could be said that the secularization process, which basically assumes that contemporary life challenges religion in new ways and those challenges weaken average religiosity over time, has not proceeded as expected in atheist China. On the contrary, the coexistence of secularization and anti-secularization emerges. Possibly, the context of Chinese religions and society proves the insight of Jose Casanova-that in our contemporary global secular age, the parallel religious and secular dynamics are ever more intertwined and interrelated (Casanova 2018b). Or perhaps, the context of Chinese religions and society proves the insight of Rob Warner-secularization is proving to be a process that is not capable of completing the journey into a fully secular society. Secularization may even be a self-limiting process, which tends (beyond a certain point) to provoke a resurgent appetite for a spiritual or religious quest (Warner 2010, p. 85). Most probably, the context of Chinese religions and society proves the insight of David Voas-fuzzy fidelity, a staging post on the road from religious to secular hegemony (Voas 2009).

Voas proposes the three categories of the religious, wholly secular and fuzzy constituencies. He uses the term fuzzy fidelity to describe the large subpopulation in between the religious and wholly secular. He says that (1) they are neither obviously religious nor completely unreligious, (2) they can be seen as a sign of secularization, or conversely as a religious market waiting for the right product to come along, (3) the proportion of fuzzy Christians will reach a plateau and then start to fall, (4) religious change in European countries follows a common trajectory whereby fuzzy fidelity rises and then falls over a very extended period. From this point, whether the proportion of more than $70 \%$ nonbelievers of Chinese adults will play the role of fuzzy fidelity or not is an open question.

If Chinese religions are studied according to secularization theories, several main differences could be easily observed. Though Chinese religions have been experiencing the increase in their wealth, influence, numbers, frequency, and close relationship to the wider society, they are also enduring a decline in their power, range of control, and prestige. Though Chinese religions have been gaining in quantitative growth recently, they are also suffering from a decline of their virtues, ethos, and religiosity.

Consequently, Chinese religions manifest several exceptional or even controversial features of the secularization thesis. On the one hand, they have experienced the reduction of their power, range of control, and prestige. On the other hand, they have embraced the increase of their members, intensity, frequency, and importance of public life. Furthermore, their holiness and vulgar increase, simultaneously. Every country's experience of religious secularization is unique, China's situation manifests some exceptions to existing secularization thesis, but what it offers is certain constructive supplements rather than overturn it. Whether they are more sacred or secular is an open question among official, religious, and common nonreligious organizations. It would be a complicated, profound, and amusing issue to discover the boundaries of the sacred and the secular and to discuss 
the degree of secularization. What can be certain is that nonreligious factors play an important role in promoting the growth of Chinese religions temporarily, while religious factors will be responsible for resurgence of Chinese religions chronically.

Funding: This research received no external funding.

Acknowledgments: Thanks to Thomas W. Ryba for providing thorough, insightful comments on numerous drafts.

Conflicts of Interest: The author declares no conflict of interest.

\section{References}

Aarts, Olav, Manfred TeGrotenhuis, Ariana Need, and Nan Dirk De Graaf. 2010. Does Duration of Deregulated Religious Markets Affect Church Attendance? Evidence from 26 Religious Markets in Europe and North America Between1981 and 2006. Journal for the Scientific Study of Religion 49: 657-72. [CrossRef]

Ashworth, Jacinta, and Ian Farthing. 2007. Churchgoing in the UK: A Research Report from Tear fund on Church Attendance in the UK. Teddington: Tearfund.

Berger, Peter L. 1967. The Sacred Canopy: Elements of a Sociological Theory of Religion. Garden City: Doubleday.

Berger, Peter L. 1997. Epistemological Modesty: An Interview with Peter Berger. Christian Century 114: 972-78.

Berger, Peter L. 1999. The Desecularization of the World: Resurgent Religion and World Politics. Washington and Grand Rapids: Ethics and Public Policy Center.

Berger, Peter L. 2014. The Many Altars of Modernity: Toward a Paradigm for Religion in a Pluralist Age. Boston: Walter deGruyter, Inc.

Brauer, Simon. 2018. The Surprising Predictable Decline of Religion inthe United States. Journal forthe Scientific Study of Religion 57: 654-75. [CrossRef]

Bruce, Steve. 2002. God Is Dead: Secularization in the West. Oxford: Blackwell.

Bruce, Steve. 2016. The sociology of late secularization: social divisions and religiosity. British Journal of Sociology 67: 613-631. [CrossRef] [PubMed]

Casanova, Jose. 1994. Public Religions in the Modern World. Chicago: University of Chicago Press.

Casanova, Jose. 2018a. Locating Religion and Secularity in East Asia Through Global Processes: Early Modern Jesuit Religious Encounters. Religions 9: 349. [CrossRef]

Casanova, Jose. 2018b. The Karel Dobbelaere lecture: Divergent global roads to secularization and religious pluralism. Social Compass 65: 187-98. [CrossRef]

Crockett, Alasdair, and David Voas. 2006. Generations of decline: Religious change in 20th-centuryBritain. Journal for the Scientific Study of Religion 45: 567-68. [CrossRef]

Finke, Roger, and Rodney Stark. 1992. The Churching of America, 1776-1990: Winners and Losers in Our Religious Economy. New Brunswick: Rutgers University Press.

Gao, Shining. 2017. The Sacred Canopy in China. Journal of the American Academy of Religion 85: 1132-36. [CrossRef]

Hadaway, C. Kirk, and Penny L. Marler. 2005. How Many Americans Attend Worship Each Week? Journal for the Scientific Study of Religion 44: 307-23. [CrossRef]

Halman, Loek, ed. 2001. The European Values Study: A Third Wave. Tilburg: Tilburg University.

Hayward, R. David, and Neal Krause. 2013. Patterns of change in religious service attendance across the life course: Evidence from a 34-year longitudinal study. Social Science Research 42: 1480-89. [CrossRef] [PubMed]

Heelas, Paul, Linda Woodhead, Benjamin Seel, Bronislaw Szerszynski, and Karin Tusting, eds. 2005. The Spiritual Revolution: Why Religion Is Giving Way to Spirituality. Oxford: Blackwell.

Lu, Yunfeng, and Chunni Zhang. 2016. Observation in Present Situation of Contemporary Chinese Christian: Based on the Survey Data from CGSS and CFPS. The World Religious Cultures 1: 34-46, 158.

Martin, David. 1969. The Religious and the Secular: Studies in Secularization. London: The Garden City Press and Routledge \& Kegan Paul.

Norris, Pippa, and Ronald Inglehart. 2004. Sacred and Secular: Religion and Politics Worldwide. New York: Cambridge University Press.

Partridge, Christopher H. 2004. The Re-Enchantment of the West. London: T \& T Clark, vol. 1.

Rossi, Maurizio, and Ettore Scappini. 2014. Church Attendance, Problems of Measurement, and Interpreting Indicators: A Study of Religious Practice in the United States, 1975-2010. Journal for the Scientific Study of Religion 53: 249-67. [CrossRef] 
Ruan, Rongping, Xiuhua Wang, and Fengtian Zheng. 2016. An economic analysis on intergenerational lock-in effects of belief in rural China. China Agricultural Economic Review 1: 170-90. [CrossRef]

Schewel, Benjamin. 2018. Post-Secularism in a World-Historical Light: The Axial Age Thesis as an Alternative to Secularization. Religions 9: 139. [CrossRef]

Scott, John. 2015. A Dictionary of Sociology. Oxford: Oxford University Press.

Stark, Rodney, and William Sims Bainbridge. 1985. The Future of Religion: Secularization, Revival, and Cult Formation. Berkeley: University of California Press.

Stark, Rodney, and Roger Finke. 2000. Acts of Faith: Explaining the Human Side of Religion. Berkeley: University of California Press.

Van Ingen, Erik, and Nienke Moor. 2015. Explanations of changes in church attendance between 1970 and 2009. Social Science Research 52: 558-69. [CrossRef] [PubMed]

Vezzoni, Cristiano, and Ferruccio Biolcati-Rinaldi. 2015. Church Attendance and Religious Change in Italy, 1968-2010: A Multilevel Analysis of Pooled Datasets. Journal for the Scientific Study of Religion 54: 100-18. [CrossRef]

Voas, David. 2009. The rise and fall of fuzzy fidelity in Europe. European Sociological Review 25: 155-68. [CrossRef]

Voas, David, and Mark Chaves. 2016. Is the United States a Counterexample to the Secularization Thesis? American Journal of Sociology 121: 1517-56. [CrossRef]

Voas, David, and Mark Chaves. 2018. Even Intense Religiosity Is Declining in the United States. Sociological Science 5: 694-710. [CrossRef]

Warner, R. Stephen. 2005. A Church of Our Own. New Brunswick: Rutgers University Press.

Warner, Rob. 2010. Secularization and Its Discontents. London: Bloomsbury Publishing PLC.

Wilson, Bryan R. 1966. Religion in Secular Society: A Sociological Comment. London: C.A Watts.

Yang, C. K. 1961. Religion in Chinese Society: A Study of Contemporary Social Functions of Religion and Some of Their Historical Factors. California: University of California Press.

Yang, Fenggang. 2007. Is Shaolin Temple Secular? Henan Social Science 15: 17-20.

(C) 2019 by the author. Licensee MDPI, Basel, Switzerland. This article is an open access article distributed under the terms and conditions of the Creative Commons Attribution (CC BY) license (http:/ / creativecommons.org/licenses/by/4.0/). 